Tlatah dan Tradisi... Oleh: A. Jauhar Fuad

\title{
TLATAH DAN TRADISI KEAGAMAAN ISLAM MATARAMAN
}

\author{
Oleh: \\ A.Jauhar Fuad \\ info.ajauharfuad@gmail.com \\ Institut Agama Islam Tribakti (IAIT) Kediri
}

\section{Abstrak}

Tulisan ini menjelaskan tlatah tradisi mataraman, proses dialogis antara budaya dan Islam dan tradisi keagamaan Islam Mataraman. Kesimpulan tulisan ini, pertama tradisi tlatah dan Mataraman pertama terkait dengan kerajaan Mataram. Dalam hal wilayah Mataraman, terletak di bagian barat Jawa Timur yang berbatasan dengan Jawa Tengah. Dari aspek sosial-politik wilayah ini memiliki pengaruh dari pekerjaan pra-Islam Mataram hingga zaman Islam. Kedua, proses pencerahan budaya terjadi melalui proses dialogis. Perjalanan menganeksasi tradisi dan budaya dengan Islam mengalami pasang surut, terkadang damai dan kadang konflik. Ketiga, tradisi keagamaan Mataraman dalam aspek-aspek tertentu memiliki persamaan. Tradisi seperti sekaten, gerebek, tahlilan, surowan dan nyadranan. Tradisi-tradisi ini dijalankan dan dilaksanakan oleh masyarakat yang dulunya berada di bawah kekuasaan kerajaan Mataram. Tradisi ini telah dimodifikasi oleh Walisongo sehingga nuansa agama Hindu-Budha yang dianggap syirik telah diubah menjadi konten Islam. Proses akulturasi melewati periode panjang berabad-abad yang melahirkan karakter masyarakat yang unik di wilayah mataraman.

Kata Kunci: Tlatah Mataraman, Tradisi Keagamaan, Islam Mataraman. 


\section{Pendahuluan}

Jawa Timur adalah provinsi terbesar dibandingkan dengan 6 provinsi lainnya di Jawa. Dengan seluas $47.922 \mathrm{~km}^{2}$, terdiri dari 29 kabupaten dan 9 kota, mayoritas penduduk di Jawa Timur adalah orang Jawa dan keduanya berbahasa Jawa dan beberapa menggunakan bahasa Madura. Ignatius Kristanto dan Yohan Wahyu yang diterbitkan menyatakan kata "Jawa" yang mengawali pada frasa "Jawa Timur" sepintas memunculkan pesan bahwa karakter budaya masyarakat yang monokultur. Tapi ternyata tidak, Jawa Timur, jika ditelaah lebih dalam, sebenarnya sangat majemuk.

Wilayah Jawa Timur terbagi menjadi sepuluh wilayah budaya. Ada empat praktik budaya utama, yaitu Mataraman, Arek, Pandalungan, dan Pulau Madura. Sedangkan skala kecil terdiri dari Osing, Tengger, Jawa Panoragan, Madura Kangean, Madura Bawean, dan Samin. Pembagian tlatah tersebut ini kemudian membedakan karakteristik masyarakat di Jawa Timur berdasarkan wilayah mereka. ${ }^{1}$ Dikatakan bahwa tlatah ini bukan untuk membedakan antara orang Jawa Timur tetapi untuk menunjukkan bahwa masyarakat Jawa Timur adalah komunitas yang unik dan kaya dalam budaya dan kearifan lokal. Bahkan perbedaan ini tidak membuat Jawa Timur melepaskan diri dari satu sama lain, masih menyatu sebagai wilayah provinsi.

1 Ayu Sutarto and Setya Yuwana Sudikan, eds., Pemetaan Kebudayaan Di Provinsi Jawa Timur: Sebuah Upaya Pencarian Nilai-Nilai Positif, Cetakan 1 (Jember: Pemerintah Provinsi Jawa Timur bekerjasama dengan Kompyawisda Jatim, 2008). 
Koentjaraningrat mengatakan ada tujuh elemen budaya yang akhirnya membuat Jawa Timur terbagi menjadi sepuluh tlatah. Ketujuh elemen ini meliputi: sistem keagamaan, sistem organisasi komunitas, sistem teknologi peralatan, sistem mata pencaharian dan/atau sistem ekonomi, sistem pengetahuan, sistem tata bahasa dan seni. ${ }^{2}$ Jadi apa perbedaan sifat dari budaya tersebut? Tulisan ini lebih fokus untuk membahas Tlatah Mataraman.

Tlatah Mataraman adalah daerah yang masih berdekat dengan budaya dan tradisi Kerajaan Mataram yang berbasis di Yogyakarta dan Surakarta. Daerah ini meliputi wilayah di Jawa Timur bagian barat, yaitu: Kabupaten Pacitan, Kabupaten Ngawi, Kabupaten Magetan, Kabupaten dan Kota Madiun, Kabupaten Nganjuk, Kota dan Kabupaten Kediri, Kabupaten Trenggalek, Kabupaten Tulungagung, Kabupaten Blitar dan Kota, Kabupaten Tuban, Kabupaten Lamongan, dan Kabupaten Bojonegoro.

Diberi nama Mataraman karena daerah ini masih memiliki keterkaitan yang kuat dari budaya Kerajaan Mataram. Jika Anda menyaksikan dari kebiasaan mereka, orang-orang di wilayah Mataraman memiliki kemirip dengan orang-orang di Yogyakarta dan Surakarta. Dari sekian kebiasaan bahasa menjadi ciri yang mencolok, penggunaan bahasa Jawa kromo dengan intonasi yang halus meskipun tidak sehalus jika

\footnotetext{
${ }^{2}$ Koentjaraningrat, “Anthropology in Indonesia," Journal of Southeast Asian Studies 18, no. 2 (1987): 217-34. 
dibandingkan dengan orang-orang yang ada Yogyakarta dan Surakarta. Tlatah Mataraman selain identik dengan kebudayaan kerajaan Mataram juga memiliki carak unik dalam penyebaran dan perkembangan Islam. Penyebaran Islam di wilayah Mataraman terjadi setelah Islam menyebar dibagian pesisir Utara pulau Jawa.

Islam Mataraman memiliki keunikan tersendiri jika dibandingan Islam yang lain. Percampuran budaya Jawa dengan ajaran Islam di Jawa terjadi dalam bentuk dialog, tetapi berbeda dengan akulturasi budaya Melayu dan ajaran Islam dengan terjadi dalam bentuk integratif. Yang terjadi, Islam menghadapi perlawanan dari tradisi dan budaya lokal, maka terjadi ketegangan dan konflik antara Islam dan Kejawen adalah ciri dari evolusi Islam di Jawa, terutama pada akhir abad ke-19 atau periode kolonial. Dipahami bahwa Islam dan budaya Jawa berkomunikasi dalam bentuk struktur sosial-keagamaan. Dipahami hubungan antara Islam dan budaya Melayu yang terjadi dalam pola integrasi, bahwa Islam telah berevolusi dan menjadi salah satu penyokong terpenting dalam struktur politik Melayu. ${ }^{3}$ Berdasarkan uraian di atas, maka tulisan ini mencoba mendeskripsikan tlatah budaya mataraman, proses dialogis antara budaya dan Islam dan tradisi keagamaan Islam Mataraman sebagai produk kebudayaan.

3 Taufik Abdullah, "Islam Dan Pembentukan Tradsisi Di Asia Tenggara" Dalam Taufik Abdullah Dan Sharon Siddique Tradisi Dan Kebangkitan Islam Di Asia Tenggara (Jakarta: LP3ES, 1989), 58-99.

Volume 30 Nomor 1 Januari-Juni 2019 


\section{Pembahasan}

\section{Tlatah Budaya Mataraman}

Tlatah budaya Jawa Mataraman berada di Jawa Timur bagian sebelah barat. Wilayah cukup luas, yang membentang dari perbatasan Provinsi Jawa Tengah hingga wilayah Kabupaten Kediri. Dinamakan Mataraman, karena masih memiliki pengaruh yang sangat kuat dari budaya Kerajaan Mataram, baik di era kejayaan Hindu-Budha maupun di era Kesultanan Mataram Islam yang berbasis di Yogyakarta dan Surakarta.

Tlatah dapat dibagi menjadi sub-wilayah budaya yang lebih kecil. Tlatah Mataram dibagi menjadi Mataraman Kulon, Mataraman Pesisir, dan Mataraman Wetan. Pembagian ini didasarkan pada perjalanan sejarah, tradisi dan budaya lokal yang berkembang di setiap daerah, dan bahasa. Bahasa adalah fitur yang paling mudah untuk membedakan. Dari segi bahasa, tradisi dan budaya dengan Jawa Tengah, Mataram Kulon lebih kuat. Bahasa sehari-hari yang digunakan lebih halus daripada Mataram Wetan. Mataraman Timur adalah tlatah Arek. Pembatas alamnya sisi timur adalah Sungai Brantas. Sungai ini telah menjadi penting sejak abad keempat, baik dari segi perdagangan, pertanian, perikanan, pelayaran maupun interaksi antara wilayah pesisir dan pedalaman. Lanskap budaya ini membentang dari Jawa Timur bagian utara ke selatan, dari Surabaya ke Malang.

Keterkaitan antara mistis dan filosofis berpadu dalam menggambarkan budaya Mataraman. Bagaimana tidak, kombinasi Jawa, Hindu dan Islam dicampur menjadi satu. Menjelaskan Mataraman bukanlah hal yang mudah. Secara historis-silsilah dan antropologi, wilayah Mataraman telah mengalami serangkaian perjalanan panjang.

Identifikasi sifat budaya Mataraman bukanlah hal yang mudah. Budaya Mataraman sangat tergantung dengan isu-isu 
historis-genealogis, etnografi, geokultural dan geopolitik. Pertama, para pemangku kepentingan budaya telah berkembang dalam situasi etnis Jawa ini, karena kebijakan-kebijakan Pemerintah kolonial sebelumnya dan Pemerintah Indonesia melalui migrasi. Kedua, pemahaman yang telah menyimpang dari kondisi historis, geopolitik, geologis dan budaya Jawa belum dapat menyimpulkan semua keadaan ini. Hal ini menyebabkan munculnya pandangan budaya Mataraman hanya terbatas pada budaya yang berkembang sebelum Indonesia merdeka di wilayah utama atau sekitar wilayah Kerajaan Mataram (Yogyakarta dan Surakarta). Ketiga, budaya Mataram terus berlanjut dan bentuknya berubah secara kontroversial dengan perubahan demografis, sosial dan ekonomi, sehingga sulit untuk menentukan Mataramán. ${ }^{4}$

Perspektif kehidupan masyarakat Mataraman masih dipengaruhi oleh filosofi kehidupan Jawa. Cara hidup orang Jawa adalah campuran dari pemikiran tradisional Jawa, keyakinan Hindu atau Budha, ajaran filosofis India dan sufisme Islam. Sedangkan basis komunitas Jawa adalah keluarga, gotong royong dan kesalehan. ${ }^{5}$

Penduduk Mataraman secara geografis terletak di tengah atau Jawa Bagian Utara yang Jawa lebih abangan. Di wilayah Mataraman, pengaruh kelompok abangan lebih kuat, yaitu bahwa agama, terutama Islam, tidak penting dalam kehidupan ruang publik dan sosial politik, maka kelompok masyarakatnya lebih terbuka terhadap ideologi politik dominan lainnya. ${ }^{6}$

4 Djoko Saryono, "Budaya Mataraman:Mencari Definisi Dan Karakteristik," in Pemetaan Kebudayaan Propinsi Jawa Timur; Sebuah Upaya Pencarian Nilai-Nilai Positif (Jember: Biro Mental Propinsi dan Kompyawisda Jatim, 2008).

${ }^{5}$ Suwardi Endraswara, Mistik Kejawen: Sinkretisme, Simbolisme, dan Sufisme dalam Budaya Apiritual Jawa (Penerbit Narasi, 2003).

6 Clifford Geertz, The Religion of Java (London: University of Chicago Press, 1976). 
Ciri yang melekat dari tradisi dan budaya kehidupan Mataraman juga memiliki implikasi bagi budaya politik mereka. Komunitas Mataraman dicirikan oleh karakteristiknya, di mana ia tidak jatuh ke dalam perangkap kesetiaan institusional. Cenderung rasional dan tidak dipengaruhi oleh kelompok agama atau organisasi. Misalnya, elit di NU Mataraman selalu mempertahankan hubungannya dengan masalah-masalah keagamaan, dan ada kecenderungan di antara mereka untuk memisahkan agama dari politik. ${ }^{7}$

\section{Islam Mataraman}

Secara historis Islam Mataraman berasal dari Islam yang berkembang selama era Kerajaan Mataram di pulau Jawa pedalaman. Karakter Muslim Mataraman membedakan mereka dari yang lain secara budaya dan politik. Ia mempertahankan bahwa Islam Mataraman tidak hanya tentang budaya, politik atau keyakinan, tetapi juga tentang integrasi di antara mereka semua. Bahwa dalam proses integrasi, agama tidak selalu menjadi pemain kunci. Sebenarnya kita tidak tertarik membahas pemenang dan yang kalah dalam proses ini. Di Mataraman bahwa integrasi adalah proses yang unik dan rumit, dan bahwa Islam di bagian Jawa ini adalah model yang sempurna tentang bagaimana agama, budaya dan politik dapat menyatu tanpa ada rasa dominasi atau marjinalisasi. ${ }^{8}$

Perkembangan Islam di wilayah Jawa Tengah dan Kesultanan Mataram penganut bermadhab Syafi'i. Ini tidak terlepas dari sejarah pertama munculnya Islam di Jawa. Sejauh

7 Abdul Chalik, "Religion and Local Politics: Exploring the Subcultures and the Political Participation of East Java NU Elites in the PostNew Order Era," Journal of Indonesian Islam 4, no. 1 (June 1, 2010): 109, https://doi.org/10.15642/JIIS.2010.4.1.109-150.

${ }^{8}$ Abdul Chalik, "Islam Mataraman dan Orientasi Politiknya dalam Sejarah Pemilu di Indonesia," ISLAMICA: Jurnal Studi Keislaman 5, no. 2 (March 1, 2011): 269, https://doi.org/10.15642/islamica.2011.5.2.269-277. 
ini, ada empat teori tentang masuk Islam ke Jawa. Teori yang sangat kuat menyatakan bahwa Islam di Jawa berasal dari wilayah barat daya India, Malabar. Kerala, salah satu daerah Malabar merupakan pusat bagi para pedagang dari Sumatra, Malaya, dan Cina. Selain memiliki kepercayaan agama yang sama, karena mereka adalah bermadhab Syafi'iyah, ada juga beberapa peninggalan antropologi bahwa ada kesamaan dalam struktur masjid di Kerala dengan masjid di Jawa. Masjid Agung Dimak, Kota Gede dan Masjid Imogiri merupakan contoh arsitektur masjid Kerala yang serupa, yang tidak ditemukan di wilayah Muslim lainnya di dunia. ${ }^{9}$

Kerajaan Mataram Islam memiliki pengaruh terhadap perkembangan Islam di Jawa Tengah dan Jawa Timur bagian barat. Misalnya: dengan munculnya pondok pesantren, lembaga yang kemudian memainkan peran dalam penyebaran mazhab Syafi'i dan merupakan tempat untuk regenerasi kader dan elit NU. Hal ini tidak dapat dipisahkan dari dari peran istana. Munculnya Tegalsari Ponorogo yang didirikan oleh Kyai Muhammad Hasan Besari atas dorongan dari Paku Buwana II (1726-1749). Hasan Besari merupakan menantu Paku Buwana II. ${ }^{10}$ Pondok Pesantren Tegalsari menjadi cikal bakal berdirinya pondok pesantren di Indonesia, sebagai salah satu institusi pendidikan penting di Indonesia.

Setelah kemunculan pesantren Tegalsari kemudian lahirlah Pondok Pesantren Termas di Pacitan. Pondok Pesantren ini didirikan dan diasuh oleh KH. Abdul Manan (1830-1842). Pada masa kecil ia bernama Bagus Darso, putra

${ }^{9}$ Mark Woodward, "Islam in Java: Normative Piety and Mysticism in the Sultanate of Yogyakarta," Islam in Java: Normative Piety and Mysticism in the Sultanate of Yogyakarta, January 1, 1989, https://asu.pure.elsevier.com/en/publications/islam-in-java-normative-pietyand-mysticism-in-the-sultanate-of-y; Merle Calvin Ricklefs, Sejarah Indonesia modern, 1200-2004 (Jakarta: Penerbit Serambi, 2005).

${ }^{10}$ Denys Lombard, Nusa Jawa: Jaringan Asia (PT Gramedia Pustaka Utama, 2005), 129. 
seorang Demang dari Semanten, yang bernama Raden Ngabehi Dipomenggolo yang masih memiliki hubungan kekerabatan dengan Raja Madjapahit, Brawijaya V. Ia belajar di pondok pesantren Tegalsari yang dipimpin oleh Kyai Hasan Besari (1800-1862). Sekembalinya dari pesantren ia dapat mendirikan Pondok Pesantren besar dengan biaya sendiri.

Pondok Pesantren Termas memiliku hubungan dengan dunia luar sebagian besar dilakukan oleh putra-putranya, yaitu kyai Mahfudz. Ia belajar ilmu agama Islam di Mekah. Ia menetap dalam jangka waktu yang cukup lama. Ia menjadi guru di Masjidil Haram. ${ }^{11}$ Sepeningal Kyai Mahfudz kemudian dilanjutkan oleh putranya, Kyai Dimyati (1894-1934). Pada masa itu pondok pesantren Termas melahirkan tokoh-tokoh penting. Kepemimpinan di Termasi dilanjutkan kyai Hamid Dimyati (1934-1948).

Sejarah perjalanan Kyai Hasan Besari selalu dikaitkan dengan perjalanan seorang Adipati Islam Batara Katong. Ia lebih dikenal sebagai Warok Ponorogo, melalui Katong akulturasi budaya dengan Islam terjadi, di mana Kyai Besari memberikan kontribusi yang cukup kuat dalam proses tersebut. ${ }^{12}$ Dimasukkannya ajaran Islam ke dalam tradisi dan budaya Jawa semakin mempercepat proses Islamisasi di kalangan masyarakat Jawa dengan memanfaatkan seni dan kebudayaan sebagai "melting pot" antara budaya Islam dan Jawa.

Mungkin bisa dimengerti jika kalangan istana lebih memperhatikan pesantren saat itu. Setelah Amangkurat I (16451677) menghancurkan Giri sebagai pusat Islam yang dipandang sebagai puncak pemisahan antara istana dengan pesantren, dan

11 Hanun Asrohah, "Pelembagaan Pesantren: Asal-Usul Dan Perkembangan Pesantren Di Jawa" (Disertasi, IAIN Syarief Hidayatullah, 2002).

12 Abdullah, "Islam Dan Pembentukan Tradsisi Di Asia Tenggara" Dalam Taufik Abdullah Dan Sharon Siddique Tradisi Dan Kebangkitan Islam Di Asia Tenggara, 188-89.

Volume 30 Nomor 1 Januari-Juni 2019 
kemudian melakukan pembunuhan kepada ribuan ulama beserta keluarga mereka. ${ }^{13}$ Setelah Giri dikalahkan, bukan berarti keberadaan pesantren itu hancur atau mati. Bahkan, pesantren memiliki peran lain dalam politik, terutama setelah digunakan sebagai tempat pengungsian bagi keluarga kerajaan yang dipindahkan. ${ }^{14}$

Pada sisi lain, perpaduan dua tradisi Islam dengan tradisi istana dapat dilihat dari keterlibatan pesantren dan istana dalam Perang Diponegoro (1825-1830) ketika melawan penjajah Belanda. Penasihat Pangeran Diponegoro dan banyak yang terlibat dalam mengobarkan semangat jihad adalah Kyai Muslim Mochammad Khalifah ${ }^{15}$ dari pesantren Madja, sekitar Delanggu di daerah sekitar Pajang yang berada di bawah pemerintahan Surakarta. Kyai Madja adalah pengasuh pesantren di desa Madja dan Baderan. Para ustad di pesantren Madja memiliki hubungan dekat dengan keluarga istana Surakarta dan Yogyakarta ${ }^{16}$.

Selain pesantren Baderan yang melakukan perlawanan terhadap Belanda ada pesantren di Madiun. Pesantren Tegalsari, pesantren Banjarsari dan pesantren Perdikan Sewulan Madiun. Dalam perang Diponogoro tidak kurang dari ada 42 Pesantren terlibat.

13 H.J. de Graaf, De Vijf Gezantschapsreizen Naar Het Hof van Mataram, 1648-1654 (S-Gravenhage: Martinus Nijhoff, 1956), https://www.google.com/search?biw=1366\&bih=608\&tbm=isch\&sa=1\&ei=8 M01XJ_ZK5nyrAHp8pfYAw\&q=De+vijf+gezantschapsreizen+naar+het+hof +van+Mataram\%2C+1648-

$1654+\% 281956 \% 29 \&$ oq=De+vijf+gezantschapsreizen+naar+het+hof+van+ Mataram\%2C+1648-

$1654+\% 281956 \% 29 \& g s \_l=i m g .3 \ldots 1183288.1183288 . .1183724 \ldots 0.0 . .0 .0 .0 \ldots$. ...1...1j2..gws-wiz-img.n8y7wsgUK9U\#imgrc=FLSBrPBiButikM:

14 M Hariwijaya, Islam Kejawen (Yogyakarta: Gelombang Pasang, 2004), 180-85.

${ }^{15}$ Kemudian sering disebut sebagai Kyai Maja merupakan ulama dari Jawa Tengah yang melakukan perlawanan terhadap gerakan pemurtadan di kalangan bangsawan dan sultan oleh masa kolonial Belanda saat itu.

16 Hanun Asrohah, Pelembagaan Pesantren; Asal-Usul Dan Perkembangan Pesantren Di Jawa (Jakarta: Depag RI, 2004), 195. 
Reuni antara istana dan pesantren ditandai dengan munculnya pondok pesantren Tegalsari Ponorogo dan beberapa pondok pesantren di Karesidenan Madiun. Peristiwa ini bagian dari penebusan kesalahan masa lalu (khusunya Amangkurat I) terhadap pesantren. Ini berarti bahwa ada saat-saat tertentu ketika keduanya tidak sejalan dan kedua belah pihak "berkelahi", tetapi ada saat-saat mereka "mesra". ${ }^{17}$ Namun, siklus harus dipahami dalam tradisi politik, bahwa siapa pun yang menentang penguasa harus ditentang bahkan walau pun mereka adalah Kyai. Konflik hanyalah sebuah tradisi, dan tidak mungkin terjadi terus-menerus, tentu ada hubungan yang harmonis antara dua entitas dunia politik dan agama. Ini sebuah tradisi yang tidak pernah hilang dalam siklus mencari hubungan antara mereka yang mewakili penguasa yang dengan ulama. ${ }^{18}$

Tradisi "gempur" dan "akur" adalah tradisi "pencampuran" yang menjadi salah satu karakter dari tradisi politik Sunni. Di mana tradisi ini telah ada sejak kekuasaan Demak. Pemerintah memberikan kebebasan kepada umat Islam untuk melaksanakan ibadah, meskipun pemerintah bukan Muslim atau demikian juga sebaliknya. Hal ini dilakukan oleh ulama (kyai) kepada Istana (kerajaan Mataram) sebagai pemerintahan yang sah tanpa menghadapinya ketika ada beberapa keputusan tidak sejalan dengan mereka. Strategi "jalan damai" menjadi tradisi politik Sunni yang merupakan ciri utama daripada Ahlussunah wal Jama'ah yang berkembang di Indonesia.

17 Abdullah, "Islam Dan Pembentukan Tradsisi Di Asia Tenggara" Dalam Taufik Abdullah Dan Sharon Siddique Tradisi Dan Kebangkitan Islam Di Asia Tenggara, 91.

${ }^{18}$ Geraint Parry, Political Elites (ECPR Press, 2005), 68. 


\section{Islam Jawa: Akulturasi Agama dan Budaya}

Perkembangan Islam di Pulau Jawa mencapai puncak prestasi ketika hadirnya fenomena unik, ketika terjadinya pergeseran pusat peradaban kerajaan Islam dari daerah Demak (pesisir) ke Mataram (pedalaman agraris) pada abad ke-17 di bawah kekuasaan Sultan Agung. Pada masa itu, paham mistisisme Jawa mengalami perkembangan sangat pesat. Raja atau sultan dipandang sebagai Sufi yang ma'rifat. Di mana kosmologi Hindu-Budha berpadu dalam wadah Sufisme. ${ }^{19}$

Konsep sufisme di atas memunculkan konsep wadah dan isi. Wadah adalah masyarakat memiliki kewajiban menjalankan syariat, sementara isi adalah raja sebagai pencetus mistisisme diperbolehkan untuk meninggalkan syariat. Pada konteks ini, Islam Jawa memang memiliki ketegangan antara penafsiran mistik dan interpretasi hukum, walau pun keduanya bersumber dari yang sama. Maka muncul varian Islam dalam bentuk 'Islam Jawa' dan 'Islam normatif'. Islam membentuk karakter tersendiri dalam interaksi sosial, politik dan kehidupan seharihari di semua lapisan masyarakat di Jawa (Woodward 1989, 3; Woodward et al. 2012).

Sejalan dengan penyataan di atas, Geertz memaparkan data yang menarik. Ia menyampaikan bahwa Islamisasi di Jawa dilakukan oleh Sunan Kalijaga, dengan mengubah ajaran Hindu ke dalam ajaran Islam. Proses Islamisasi di Jawa dilakukan dengan mengakomodasi tradisi dan kepercayaan lokal. Temuan ini berbeda di Afrika Utara (Maroko), di mana dakwah Islam bertentangan dengan tradisi dan kepercayaan lokal, dengan lebih menggunakan pendekatan pemurnian. ${ }^{20}$

${ }^{19}$ Abdullah, "Islam Dan Pembentukan Tradsisi Di Asia Tenggara" Dalam Taufik Abdullah Dan Sharon Siddique Tradisi Dan Kebangkitan Islam Di Asia Tenggara, 58-99.

${ }^{20}$ Geertz, The Religion of Java. 
Islamisasi di Jawa yang mengakomodasi tradisi dan dinamika kearifan lokal. Hal ini, tercermin dalam berbagai karya sastra zaman ini. Misalnya: karya sastra yang dimaksud menggambarkan gaya akulturasi antara budaya Islam dan Jawa, seperti yang digambarkan, antara lain, dalam 'Babad Jawa' dan 'Serat Sentini'. Sufisme dicirikan oleh serat sebagai budaya Jawa dengan istilah yang unik. Dengan Islamisasi Jawa (sebagaimana beberapa orang menyebutnya sebagai javanasi Islam), adalah logis bahwa pada tahap selanjutnya orang-orang Jawa akan memiliki sikap toleransi terhadap budaya atau pengikut agama-agama lain.

Orang Jawa memiliki sikap toleransi yang tinggi terhadap pengikut agama lain. Seperti yang dijelaskan di bagian selanjutnya; tentu saja saya muslim, tetapi tidak fanatik seperti orang muslim yang di Aceh. Kita, orang Jawa, bisa selaras dengan orang Hindu, Budha dan Budha. Kami melihat kebenaran dalam semua agama di dunia dan tidak hanya (secara eksklusif) dalam keyakinan kami. ${ }^{21}$

Toleransi dan penghormatan terhadap agama, tradisi dan budaya, bagi orang Jawa adalah suatu kebanggaan. Sikap seperti ini tidak dapat lepas dari legenda Jawa yang digambarkan dalam dunia wayang. Cerita wayang dalam kisah Mahabarata telah terserap ke dalam mentalitas Jawa. Cerita Mahabarata dalam wayang di Jawa telah memberikan kepribadian yang berbeda mewakili keunikan pribadi orang Jawa. Ini bisa dilihat, misalnya, dalam karakter Yudhistira, merupakan simbol raja yang bijaksana dengan mantra suci Kalimasaha. Arjuna adalah simbol kehendak lembut dan kuat. Bima adalah seorang pejuang pemberani yang tidak memiliki belas kasih kepada lawanlawannya tetapi memiliki komitmen yang kuat terhadap kejujuran dan kesetiaan. Baladewa sebagai guru Parikesit cucu

21 Benedict C Anderson, Mitologi Dan Toleransi Orang Jawa (Yogyakarta: Qolam, 2000), 4. 
Arjuna, Kakek Raja-raja tanah Jawa. Subadra mendapatkan julukan sebagai aristokrat Jawa. Krishna adalah simbol diplomatik yang sangat baik dan lainnya. ${ }^{22}$

Gambaran tentang mitologi pewayangan mencakup konstruk pemikiran dan budaya yang membuat orang Jawa tampak relatif toleran dan luas. Pada abad ketujuh belas, gaya dialog ini lebih harmonis daripada konfrontasi. Tetapi sejak abad ke-19, bersama dengan penjajahan Barat atas kepulauan (termasuk Jawa) kolonialisme lebih banyak disukai kelompok priyayi, konflik antara Santri (Islam) dan Priyayi tidak bisa dihindari. Akibatnya, beberapa karya Satra, seperti Serat Gatholoco, Serat Darmagandhul, dan Serat Cebolek, juga memiliki ketepatan dalam memfitnah santri. Sastra itu mewakili ideologi priyayi, yang sebagian besar memiliki konotasi teologis dengan animisme dan Hindu. Ini dapat dilihat, misalnya, dalam deskripsi ideologis tentang serat di sekitar santri. Kata Mekah, misalnya, ditafsirkan sebagai Mekah, yang berarti di Jawa pembukaan paha / kaki seperti posisi hubungan seksual dan lainlain. Ini tentu merugikan Santri, karena perilaku atau ekspresi kesantrian digambarkan dengan cara yang negatif dan tidak bermoral sehingga Islam dianggap sebagai agama asing bagi orang Jawa.

Dibandingkan dengan daerah lain di kepulauan ini, toleransi Jawa dengan agama lain umumnya tetap tinggi. Toleransi yang diekspresikan oleh umat Islam Jawa bukanlah toleransi murni, melainkan semacam "konsiliasi" dengan tradisi pra-Islam, terutama animisme dan Hindu. Maka hampir tidak ada perbedaan antara toleransi dan rekonsiliasi Islam Jawa dengan beberapa agama yang ada. Ini karena mereka memiliki kebajikan dan kearifan lokal, yang diambil dari akar budaya

\footnotetext{
${ }^{22}$ Anderson, Mitologi Dan Toleransi Orang Jawa.
} 
yang berbeda, ajaran filosofis, ajaran agama dan tradisi yang berakar. Bahkan jauh sebelum keberadaan Islam di Nusantara. ${ }^{23}$

Kehidupan masyarakat Islam dipengaruhi oleh kepercayaan tradisional Jawa yang diajarkan oleh kakek buyut mereka sehingga mitos tentang kekuatan tak terlihat dari manusia dapat mempengaruhi kehidupan sosial. Ada tiga macam variasi agama seperti Islam Abangan dan Islam Santri, namun Santri terbagi menjadi generasi muda dan generasi tua. ${ }^{24}$

\section{Tradisi Keagamaan Islam Mataraman}

Keberhasilan dakwah di suatu wilayah tidak hanya ditentukan oleh kualitas ajaran agamanya, akan tetapi yang lebih penting, bagaimana proses mentransfer ajaran kepada pengikut. Di Jawa, orang mengenal agama melalui proses yang unik, menarik dan dinamis. Meskipun proses itu telah berlangsung selama berabad-abad sebagaimana yang dilakukan oleh Walisongo di Jawa. Walisongo di Jawa melaukan pertukaran budaya Jawa dengan Islam, yang menghasilkan budaya Islam dan budaya Jawa.

Tradisi keagamaan menjadi ciri Islam yang ada di Mataraman, yang sampai dengan saat ini tradisi tersebut terus dipertahankan. Ada pun beberapa tradisi yang masih ada seperti:

1. Tradisi Tahlilan

Tahlilan adalah perayaan atau upacara keselamatan untuk berdoa kepada Tuhan dengan membaca surat Yasin dan dilanjutkan dengan membaca banyak surat dan ayat lain yang dipilih, diikuti oleh kalimat tahlil (laailaahaillallah), tahmid (alhamdulillah) dan tasbih (subhanallah). Biasanya diadakan

23 Ummi Sumbulah, "Islam Jawa Dan Akulturasi Budaya: Karakteristik, Variasi dan Ketaatan Ekspresif," El Harakah 14, no. 1 (December 1, 2012): 66, https://doi.org/10.18860/el.v0i0.2191.

${ }^{24}$ M. Dimyati Huda, "The Variation of Javanese Islamic Society in the Existence of Paranormal," Journal of Development Research 1, no. 2 (November 1, 2017): 45, https://doi.org/10.28926/jdr.v1i2.20.

Volume 30 Nomor 1 Januari-Juni 2019 
sebagai rasa sukur kepada Allah SWT atas segala nikmat yang diterimannya (tasyakuran) dan doa untuk orang yang telah meninggal pada hari ke 1 sampai dengan ke 7, hari ke 40, hari ke 100, haul pertama dan haul ke dua, hari ke 1000 mendak ke tiga (Haul ke 3). ${ }^{25}$ Tahlil, artinya pengucapan kalimat "Laa ilaaha illallaah". Tahlilan artinya bersama-sama memanjatkan doa bagi orang-orang yang sudah meninggal dunia agar dosadosanya diampuni oleh Allah. ${ }^{26}$

Tradisi ini pada dasarnya berasal dari adat-istiadat Hindu dan Budha, yaitu pesta, keselamatan dan pengorbanan. Dalam Islam, menggap tradisi ini tidak dapat dibenarkan karena mengandung syirik. Namun mara Walisongo mengemas tradisi ini dengan ajaran Islam. Dalam tahlilan sesaji diganti dengan berkah atau nasi dan lauk yang diberikan oleh peserta. Wali yang mengubah tradisi ini adalah Sunan Kalijaga, sehingga orang-orang yang masuk agama Islam tidak terkejut, karena mereka harus meninggalkan tradisi leluhurnya, sehingga mereka kembali ke agama aslinya. Tradisi tahlilan juga ditemuakan dalam kegiatan menjelang pernikahan, kehamilan dan kelahiran. ${ }^{27}$ Tahlil adalah salah satu kearifan lokal atau tradisi yang masih dipertahankan dan berlanjut hingga hari ini di masyarakat. ${ }^{28}$

25 Muhammad Sholikhin, Ritual Dan Tradisi Islam Jawa: RitualRitual dan Tradisi-Tradisi Tentang Kehamilan, Kelahiran, Pernikahan, dan Kematian Dalam Kehidupan Sehari-Hari Masyarakat Islam Jawa (Penerbit Narasi, 2010); M. Madchan Anies, Tahlil dan Kenduri: Tradisi Santri dan Kiai (Yogyakarta: PT LKiS Pelangi Aksara, 2009).

26 Muhtadin Muhtadin, "Sosialiasi Yasinan dan Tahlilan dalam Komunikasi Islam (Disampaikan pada Jamaah Masjid Al Adil - Jakarta Selatan)," Jurnal ABDI MOESTOPO 1, no. 01 (January 27, 2018): 23.

${ }^{27}$ Sholikhin, Ritual dan tradisi Islam Jawa.

${ }^{28}$ Andi Warisno, "Tradisi Tahlilan Upaya Menyambung Silaturahmi," Ri'ayah: Journal of Social and Religious 2, no. 02 (December 21, 2017): 69. 
2. Tradisi Sekaten

Sekaten merupakan tradisi ekspresi musik gamelan. Tradisi ini pertama kali itu terjadi di Pulau Jawa. Hal ini, sebagai sarana penyebaran Islam yang dilakukan oleh Sunan Bonang. Di masa lalu, setiap kali Sunan Bonang memaikan gamelan selalui diselingi dengan lagu-lagu yang berisi ajaran Islam. Setiap perubahan lagu dalam pukulan Gamelan diselingi dengan pengunjuk diminta membacaan syahadatain, yang pada akhirnya tradisi ini disebut 'sekatenan'. Tujuan dari sekaten adalah syahadatain (membaca dua kalimat syadat). ${ }^{29}$ Sekaten juga syarat akan nuansa politik dan budaya pada akhir abad 20 sampai awal abad $21 .^{30}$

Sekaten juga dimainkan bertepatan dengan Grebek Maulud. Acara puncak dalam tradisi sekaten adalah pelepasan sepasang gunung dari Masjidil Agung setelah didoakan oleh ulama kerajaan. Banyak orang berpikir bahwa siapa pun yang mendapat sedikit atau terlalu banyak makanan dari Gunungan akan mendapat berkah dalam hidupnya. Beberapa hari sebelum pembukaan sekaten, sebuah pesta rakyat diadakan. Sekaten merupakan upacara untuk memperingati Maulid Nabi Muhammad yang dilakukan oleh keluaraga Istana di Yogyakarta. Selain itu maulud sekaten diadakan di Bulan Agung (dzulhijjah). Selama perayaan ini, dua gunungan diarak dari istana ke Lapangan Masjid Agung di Yogyakarta.

${ }^{29}$ Joko Daryanto, "Gamelan Sekaten Dan Penyebaran Islam Di Jawa," Keteg : Jurnal Pengetahuan, Pemikiran Dan Kajian Tentang Bunyi 14, no. 1 (January 25, 2016), https://jurnal.isiska.ac.id/index.php/keteg/article/view/665; A. Adaby Darban, "Ulama Jawa dalam Perspektif Sejarah," Jurnal Humaniora 16, no. 1 (August 4, 2012): 27-34, https://doi.org/10.22146/jh.v16i1.804.

30 Izzatun Ni'mah, “Keramaian (Dan) Sekaten Yogyakarta 19382005" (Universitas Gadjah Mada, 2007), http://etd.repository.ugm.ac.id/index.php?mod=penelitian_detail\&sub=Peneli tianDetail\&act=view\&typ=html\&buku_id=36197.

Volume 30 Nomor 1 Januari-Juni 2019 
Pengaruh Islam di pusat kerajaan seringkali menggunakan cara-cara tradisional yang telah dipelihara oleh rakyat selama beberapa generasi. Masyarakat setempat menerima kehadiran Islam sebagai pelengkap kebutuhan spiritual mereka sehingga keseimbangan hidup tercapai. Perayaan sekaten sebagai manifestasi pencampuran budaya menyangkut berbagai aspek multidimensional. Islam berpadu dengan budaya lokal secara elastis, keduanya terkait dengan pengenalan simbol-simbol Islam dan ritual keagamaan ${ }^{31}$.

Penyebaran agama Islam di Jawa menggunakan banyak cara atau metode untuk menyebarkan iman Islam. Salah satu medium yang mendukung penyebaran Islam di Jawa adalah 'Gamelan Sekaten'. Ini adalah semacam ensemble yang dimainkan pada kesempatan maulud Nabi Muhammad dan dimainkan selama 1 minggu di 'Bangsal Pagongan' di depan Masjid Agung Surakarta ${ }^{32}$.

Sebelum orang Jawa mengetahui dan berubah menjadi iman Islam, orang Jawa telah diubah menjadi agama Hindu \& Budha. Kondisi sosial psikologis orang Jawa ini menjadi kendala bagi sembilan orang suci muslim, Wali Sanga, untuk menyebarkan agama Islam. Sunan Kalijaga menyarankan menggunakan 'gamelan' sebagai daya tarik penyebaran Islam. 'gamelan sekaten' yang digunakan sebagai media penyebaran Islam di Jawa sangat berasumsi bahwa media ini memiliki nilai atau elemen Islam.

Orang Jawa pada waktu itu masih memiliki keyakinan yang kuat terhadap agama Hindu \& Budha, sehingga diperlukan alat, dalam hal ini adalah 'gamelan sekaten', untuk memfasilitasi sembilan orang suci muslim dalam menyebarkan

${ }^{31}$ Hadawiyah Endah Utami, "Kidung Sekaten Antara Religi Dan Ritus Sosial Budaya," Harmonia: Journal of Arts Research and Education 11, no. 2 (2011), https://doi.org/10.15294/harmonia.v11i2.2208.

32 Daryanto, "Gamelan Sekaten Dan Penyebaran Islam Di Jawa." 
Iman Islam. Strategi dakwah agama ini yang menggunakan 'gamelan sekaten' sebagai media tampaknya sangat menarik dan efektif untuk mengumpulkan orang. Diawali dengan rasa tertarik pada 'gameln sekaten', akhirnya, orang Jawa tahu dan masuk Islam sebagai keyakinan mereka. Proses Islamisasi ini, disebut sebagai dakwah agama menggunakan pendekatan budaya. ${ }^{33}$

3. Tradisi Grebek

Grebek adalah tradisi Jawa untuk menemani raja. Tradisi ini pertama kali diadakan oleh Keraton Yogyakarta pada masa Sultan Hamengkubuwana ke-1. Grebek dilakukan ketika Sultan akan menunaukan hajat dalem dalam bentuk menikahi putra mahkotanya. Di Istana Yogyakarta Grebek diadakan 3 kali setiap tahun, yaitu: Pertama grebek pasa (puasa) diadakan untuk menghormati bulan Ramadan dan Lailatul Qadar, grebek syawal diadakan setiap tanggal 1 Syawal, perayaan kemenangan bagi umat Islam dalam merekayan Hari Raya Idul Fitri. Kedua, grebek besar diadakan pada setiap tanggal 10 Dhulhijjah untuk merayakan pengorbanan nabi Ismail dan ketiga grebek maulud setiap tanggal 12 Rabiul awal untuk memperingati ulang tahun Nabi Muhammad. Selain di kota Yogyakarta, yang menyengengakan pesta grebek, adalah Solo, Cirebon, lalu Demak. Acara ini adalah puncak dari perayaan maulud. Pada malam hari tanggal 11 Rabiul Awal, Sultan, keluarga dan pejabat istana Yogyakarta hadir di Masjid Agung. Maulid Nabi Muhammad adalah salah satu acara grebek adalah tradisi Jawa yang menyertai raja atau penguasa kerajaan. ${ }^{34}$

Masyarakat Jawa selalu melakukan ritual religiusitas yang bertujuan untuk mendapatkan kedamaian dan harmoni. Ajaran Islam yang berpadu dengan budaya Jawa lebih bernilai. Identitas

\footnotetext{
${ }^{33}$ Daryanto.

34 Thoha Hamim, "Tradisi Maulid Nabi Di Kalangan Masyarakat Pesantren," Religió: Jurnal Studi Agama-Agama 4, no. 2 (2014), http://religio.uinsby.ac.id/index.php/religio/article/view/50.

Volume 30 Nomor 1 Januari-Juni 2019 
lokal menjadi alat dakwah Islamiyah. Multikulturalisme dan semangat toleransi memberi pencerahan pada lingkungan ${ }^{35}$.

4. Tradisi Suranan

Bulan Muharram dikenal, oleh orang Jawa menyebutnya bulan Suro atau bulan Asyura. ${ }^{36}$ Suranan (suro) dalam kalender Islam adalah bulan Muharram. Pada bulan itu orang Islam di Jawa mengunjungi makam orang-orang suci. Selain itu, mereka juga membuat dan membagikan makanan khas dalam bentuk bubur (bubur suro), yang melambangkan terima kasih Tuhan Yang Maha Esa.

Berbeda dengan muslim pada umumnya yang merayakan bulan Muharram, dengan puasa, bacaan yasin atau bacaan surat al-Ikhlas, sedekah kepada orang miskin dan anak yatim. Orang Islam di Jawa mengadakan upacara suroan dengan tradisi yang lebih khusus. ${ }^{37}$

Bahwa tradisi ini hanya terjadi pada umat Islam di Jawa, namun masih ada kelompok orang yang membedakan antara Islam dan Jawa. Bagi mereka, Jawa dan Islam merupakan dua entitas, yang masing-masing mandiri. Islam adalah masalah tersendiri sebagai sebuah ajaran suci, jadi Jawa adalah hal lain sebuah wilayah. Entitas budaya, Islam dan Jawa adalah hal yang berbeda. Pada saat yang sama, ada juga beberapa yang mengklaim bahwa Islam dan Jawa adalah dua entitas. Mereka telah lama membangun budaya memberi dan menerima dialog. Pendapat kedua ini menjadi arus utama belakangan ini.

Islam dan Jawa telah menjadi entitas budaya yang tidak dapat dipisahkan. Ini seperti mata uang, jadi satu aspek ada

35 Purwadi Purwadi, "Harmony Masjid Agung Kraton Surakarta Hadiningrat,” IBDA ` Jurnal Kajian Islam Dan Budaya 12, no. 1 (2015): 72, https://doi.org/10.24090/ibda.v12i1.437.

36 Andik Wahyun Muqoyyidin, "Dialektika Islam dan Budaya Lokal dalam Bidang Sosial Sebagai Salah Satu Wajah Islam Jawa," El Harakah 14, no. 1 (December 1, 2012): 18, https://doi.org/10.18860/el.v0i0.2197.

37 Nur Syam, "Tradisi Muharram (Suroan) Di Nusantara," 2018, http://nursyam.uinsby.ac.id/?p=4310. 
Islam dan sisi lain ada Jawa. Jadi tidak bisa dipisahkan keduanya. Dari sudut pandang ini, Islam dapat bekerja sama dengan tradisi Jawa. Islam dan Jawa dapat membangun demokrasi dan modernitas. Keduanya saling berkontribusi dalam satu unit untuk membangun tradisi dan peradaban yang hebat dan universal.

Islam dan Jawa sebenarnya adalah entitas budaya yang dapat memberikan warna khas untuk Islam dibandingkan dengan Islam di beberapa tempat lain. Keunikannya terletak pada banyak tradisi keagamaan yang tidak sering ditemukan dalam praktik Islam di tempat lain, bahkan di pusat asal muasal Islam di Timur Tengah. Oleh karena itu, ada beberapa hal yang dapat dipahami sehubungan dengan perilaku muslim Jawa, yang terkait dengan ketaatan 1 suro, termasuk: tradisi membersihkan/memcuci keris atau benda pusaka waris lainnya. ${ }^{38}$

Bulan Suro atau bulan Muharram adalah bulan bulan suci. Karena itu, banyak orang Jawa melakukan berbagai tradisi untuk mendapatkan keselamatan dan keberkahan. Tentu saja, kita tidak dapat menilai apakah pelaksanaan perayaan ini memiliki argumen tasi atau tidak. Tetapi satu hal penting adalah bahwa mereka beryakinan bahwa bulan ini harus menjadi semua lelakon.

5. Tradisi Nyadran

Istilah nyadran berasal dari kata sadran dalam bahasa Jawa yang berarti ziarah atau nikkar, dalam bahasa Kawi dari kata sraddha yang berarti memperingati hari kematian seseorang. Nyandran merupakan tradisi Jawa yang memiliki tujuan untuk menghormati orang tua, nenek moyang atau leluhur mereka yang sudah meninggal dengan melakukan kegiatan ziarah, nyekar ke kuburan dan berdoa untuk mohon apunan kepada Allah atas kesalahan mereka. Di daerah lain nyandran

${ }^{38}$ Syam.

Volume 30 Nomor 1 Januari-Juni 2019 
diartikan membersihkan makam (kubur) kakek-nenek dan sedulur, kemudian membersihkan desa.

Tradisi nyadran penuh makna simbolis. Tradisi nyadran memiliki kandungan religi yang sangat kental, keseluruhan mengandung makna religius yang sangat kental dengan tiga unsur, yaitu: syukur, sedekah, dan ketulusan. Makna nyadran dalam kehidupan sosial menjadi tempat transformasi budaya dalam membangun hubungan keluarga, gotong royong, solidaritas, ekonomi, rasa tanggung jawab, egaliter, dan kebersamaan dari semua lapisan masyarakat. Tradisi nyadran mampu menjadi tempat pertemanan, perekat sosial tanpa terpecah dalam status sosial, kelas, agama, atau apa pun pada kebenaran secara subjektif. ${ }^{39}$

Tradisi nyadran adalah makna simbolis dari hubungan dengan leluhur, sesama manusia, dan Yang Maha Kuasa untuk segalanya. Nyadran adalah pola ritual yang mencampur budaya lokal dan nilai-nilai Islam, sehingga ada wilayah yang sangat kental dalam Islam. Budaya masyarakat yang telah melekat erat membuat masyarakat Jawa sangat menjunjung nilai-nilai luhur budaya itu. Dengan demikian tidak mengherankan bahwa penerapan nyadran masih kental dengan budaya Hindu, dinamisme dan animistik yang diaktualisasikan dengan nilainilai Islami oleh Wali Sanga. Nyadran dilihat dari perspektif budaya Jawa untuk bersyukur atas rezeki Allah melalui perayaan. Orang percaya bahwa jika mereka memberi sedekah, Tuhan akan memberikan "hadiah" yang layak. Sementara persembahan adalah aktualisasi pikiran, keinginan dan perasaan para aktor untuk lebih dekat dengan Tuhan. ${ }^{40}$

39 A. Jauhar Fuad, "Makna Simbolik Tradisi Nyadran," Jurnal IAI Tribakti Kediri, 13, no. 2 (2013): 133.

${ }^{40}$ Fuad, 131. 


\section{Penutup}

Tulisan ini, dapat menarik kesimpulan sebagai berikut; pertama tlatah dan tradisi Mataraman berkait dengan kerajaan Mataram. Dari segi wilayah Mataraman berda di Jawa Timur bagian Barat yang berbatasan dengan Jawa Tengah. Dari aspek sosio-politik wilayah ini memiliki pengaruh dari kerjaan Mataram baik pra Islam sampai dengan masa Islam. Dari segi tradisi, ada persamaan tlatah Mataraman dengan daerah Yogyakarta dan Surakarta persamaan yang paling identik darinya adalah aspek bahasa. Kedua, proses percampuran budaya terjadi melalui proses dialogis, baik Mataram pra Islam sampai dengan Mataram Islam. Perjalan pencampuran tradisi dan budaya dengan Islam terjadi pasang surut, terkadang damai dan terkadang konflik, yang terwujud dalam monumen lahirnya Pondok Pesantren Tegalsari di Ponorogo dan perang Diponogoro. Ketiga, tradisi keagamaan mataraman pada aspek tertentu memiliki persamaan dengan kerajaan mataraman. Tradisi itu seperti sekaten, grebek, tahlilan, surowan dan nyadranan. Tradisi-tradisi tersebut dijalankan dan dilestarikan pada masyarakat yang dulunya berada di bawah kekuasaan kerajaan Mataram. Tradisi tersebut sejatinya sudah termodifikasi oleh Walisongo sehingga yang awalnya bernuansa agama Hindu-Budha diubah menjadi muatan yang bersifat Islami. Proses akulturasi berjalan melalui waktu yang panjang berabadabad yang melahirkan karakter masyarakat yang unik di wilayah Mataraman.

\section{Ucapan Terimakasih}

Saya menyampaikan banyak terima kasih kepada Direktorat Pendidikan Tinggi Islam Direktorat Jenderal Pendidikan Islam Kementerian Agama RI yang telah memberikan dana Hibah Penelitian Sosial Kritis Tahun Anggaran 2018. 


\section{DAFTAR PUSTAKA}

Abdullah, Taufik. "Islam Dan Pembentukan Tradsisi Di Asia Tenggara" Dalam Taufik Abdullah Dan Sharon Siddique Tradisi Dan Kebangkitan Islam Di Asia Tenggara. Jakarta: LP3ES, 1989.

Anderson, Benedict C. Mitologi Dan Toleransi Orang Jawa. Yogyakarta: Qolam, 2000.

Anies, M. Madchan. Tahlil dan Kenduri: Tradisi Santri dan Kiai. Yogyakarta: PT LKiS Pelangi Aksara, 2009.

Asrohah, Hanun. "Pelembagaan Pesantren: Asal-Usul Dan Perkembangan Pesantren Di Jawa." Disertasi, IAIN Syarief Hidayatullah, 2002.

—. Pelembagaan Pesantren; Asal-Usul Dan Perkembangan Pesantren Di Jawa. Jakarta: Depag RI, 2004.

Chalik, Abdul. "Islam Mataraman dan Orientasi Politiknya dalam Sejarah Pemilu di Indonesia." ISLAMICA: Jurnal Studi Keislaman 5, no. 2 (March 1, 2011): 26977. https://doi.org/10.15642/islamica.2011.5.2.269-277.

_. "Religion and Local Politics: Exploring the Subcultures and the Political Participation of East Java NU Elites in the Post-New Order Era." Journal of Indonesian Islam 4, no. 1 (June 1, 2010): 109-50. https://doi.org/10.15642/JIIS.2010.4.1.109-150.

Darban, A. Adaby. "Ulama Jawa dalam Perspektif Sejarah." Jurnal Humaniora 16, no. 1 (August 4, 2012): 27-34. https://doi.org/10.22146/jh.v16i1.804.

Daryanto, Joko. "Gamelan Sekaten Dan Penyebaran Islam Di Jawa." Keteg: Jurnal Pengetahuan, Pemikiran Dan Kajian Tentang Bunyi 14, no. 1 (January 25, 2016). https://jurnal.isiska.ac.id/index.php/keteg/article/view/665. 
Endraswara, Suwardi. Mistik Kejawen: Sinkretisme, Simbolisme, dan Sufisme dalam Budaya Apiritual Jawa. Penerbit Narasi, 2003.

Fuad, A. Jauhar. "Makna Simbolik Tradisi Nyadran.” Jurnal IAI Tribakti Kediri, 13, no. 2 (2013).

Geertz, Clifford. The Religion of Java. London: University of Chicago Press, 1976.

Graaf, H.J. de. De Vijf Gezantschapsreizen Naar Het Hof van Mataram, 1648-1654. S-Gravenhage: Martinus Nijhoff, 1956.

https://www.google.com/search?biw=1366\&bih=608\&t bm=isch\&sa=1\&ei=8M01XJ_ZK5nyrAHp8pfYAw\&q= De+vijf+gezantschapsreizen+naar+het+hof+van+Matar am\%2C+1648-

$1654+\% 281956 \% 29 \&$ oq=De+vijf + gezantschapsreizen +naar+het+hof+van+Mataram\%2C+1648$1654+\% 281956 \% 29 \&$ gs_l=img.3...1183288.1183288.. $1183724 \ldots 0.0 .0 .0 .0 \ldots \ldots .1 \ldots .1 \mathrm{j} 2 . . \mathrm{gws}-\mathrm{wiz}-$ img.n8y7wsgUK9U\#imgrc=FLSBrPBiButikM:

Hamim, Thoha. "Tradisi Maulid Nabi Di Kalangan Masyarakat Pesantren.” Religió: Jurnal Studi Agama-Agama 4, no. 2

http://religio.uinsby.ac.id/index.php/religio/article/view 150 .

Hariwijaya, M. Islam Kejawen. Yogyakarta: Gelombang Pasang, 2004.

Huda, M. Dimyati. "The Variation of Javanese Islamic Society in the Existence of Paranormal." Journal of Development Research 1, no. 2 (November 1, 2017): 45-54. https://doi.org/10.28926/jdr.v1i2.20.

Koentjaraningrat. "Anthropology in Indonesia." Journal of Southeast Asian Studies 18, no. 2 (1987): 217-34.

Lombard, Denys. Nusa Jawa: Jaringan Asia. PT Gramedia Pustaka Utama, 2005. 
Muhtadin, Muhtadin. "Sosialiasi Yasinan dan Tahlilan dalam Komunikasi Islam (Disampaikan pada Jamaah Masjid Al Adil - Jakarta Selatan).” Jurnal ABDI MOESTOPO 1, no. 01 (January 27, 2018): 23-29.

Muqoyyidin, Andik Wahyun. "Dialektika Islam dan Budaya Lokal dalam Bidang Sosial Sebagai Salah Satu Wajah Islam Jawa." El Harakah 14, no. 1 (December 1, 2012): 18-33. https://doi.org/10.18860/el.v0i0.2197.

Ni'mah, Izzatun. "Keramaian (Dan) Sekaten Yogyakarta 19382005." Universitas Gadjah Mada, 2007. http://etd.repository.ugm.ac.id/index.php?mod=peneliti an_detail\&sub=PenelitianDetail\&act=view \& typ $=\mathrm{html}$ \&buku_id=36197.

Parry, Geraint. Political Elites. ECPR Press, 2005.

Purwadi, Purwadi. "Harmony Masjid Agung Kraton Surakarta Hadiningrat." IBDA : Jurnal Kajian Islam Dan Budaya 12, no. 1 (2015): 72-84. https://doi.org/10.24090/ibda.v12i1.437.

Ricklefs, Merle Calvin. Sejarah Indonesia modern, 1200-2004. Jakarta: Penerbit Serambi, 2005.

Saryono, Djoko. "Budaya Mataraman:Mencari Definisi Dan Karakteristik." In Pemetaan Kebudayaan Propinsi Jawa Timur; Sebuah Upaya Pencarian Nilai-Nilai Positif. Jember: Biro Mental Propinsi dan Kompyawisda Jatim, 2008.

Sholikhin, Muhammad. Ritual Dan Tradisi Islam Jawa: RitualRitual dan Tradisi-Tradisi Tentang Kehamilan, Kelahiran, Pernikahan, dan Kematian Dalam Kehidupan Sehari-Hari Masyarakat Islam Jawa. Penerbit Narasi, 2010.

Sumbulah, Ummi. "Islam Jawa Dan Akulturasi Budaya: Karakteristik, Variasi dan Ketaatan Ekspresif." El Harakah 14, no. 1 (December 1, 2012): 51-68. https://doi.org/10.18860/el.v0i0.2191. 
Sutarto, Ayu, and Setya Yuwana Sudikan, eds. Pemetaan Kebudayaan Di Provinsi Jawa Timur: Sebuah Upaya Pencarian Nilai-Nilai Positif. Cetakan 1. Jember: Pemerintah Provinsi Jawa Timur bekerjasama dengan Kompyawisda Jatim, 2008.

Syam, Nur. "Tradisi Muharram (Suroan) Di Nusantara," 2018. http://nursyam.uinsby.ac.id/?p=4310.

Utami, Hadawiyah Endah. "Kidung Sekaten Antara Religi Dan Ritus Sosial Budaya." Harmonia: Journal of Arts Research and Education 11, no. 2 (2011). https://doi.org/10.15294/harmonia.v11i2.2208.

Warisno, Andi. "Tradisi Tahlilan Upaya Menyambung Silaturahmi." Ri' ayah: Journal of Social and Religious 2, no. 02 (December 21, 2017): 69-97.

Woodward, Mark. "Islam in Java: Normative Piety and Mysticism in the Sultanate of Yogyakarta." Islam in Java: Normative Piety and Mysticism in the Sultanate of Yogyakarta, January 1, 1989. https://asu.pure.elsevier.com/en/publications/islam-injava-normative-piety-and-mysticism-in-the-sultanateof-y. 